Dwi Aulia Permatasari, Gusti Irhamni, Didi Susanto

Jurnal Mahasiswa BK An-Nur : Berbeda, Bermakna, Mulia

Volume 4 Nomor 1 Tahun 2018

Tersedia Online: https://ojs.uniska-bjm.ac.id/index.php/AN-NUR

ISSN. 2460-9722

\title{
PERAN GURU BIMBINGAN DAN KONSELING TERHADAP PENINGKATAN PRESTASI BELAJAR PESERTA DIDIK SMP NEGERI 1 PADANG BATUNG
}

\author{
Dwi Aulia Permatasari, Gusti Irhamni, Didi Susanto \\ Universitas Islam Kalimantan Muhammad Arsyad Al-Banjari \\ dwiaulia230@gmail.com
}

\begin{abstract}
ABSTRAK
Objek dalam penelitian ini adalah Peran guru bimbingan dan konseling terhadap peningkatan prestasi belajar siswa kelas VIII di SMP Negeri 1 Padang Batung dengan Subyek penelitian yaitu 1 orang guru bimbingan dan konseling di SMP Negeri 1 Padang Batung.Teknik pengumpulan data yang digunakan dalam penelitian ini adalah wawancara, observasi .

Hasil dari penelitian ini menunjukan bentuk layanan bimbingan belajar yang diberikan oleh guru bimbingan dan konseling kepada siswa dalam meningkatkan prestasi belajar siswa kelas VIII di SMP Negeri 1 Padang Batung Kecamatan Padang Batung Kabupaten Hulu Sungai Selatan dengan cara memberikan layanan bimbingan belajar didalam kelas maupun memanggil siswa yang mempunyai masalah belajar yang mempengaruhi prestasi belajarnya keruang bimbingan dan konseling untuk diberikkan arahan-arahan, diperbaiki dan ditingkatkan agar menjadi siswa yang unggul dalam prestasi belajarnya.

Berdasarkan hasil penelitian ini disarankan Bagi pihak sekolah dan instansi terkait terhadap pelaksanakan layanan bimbingan belajar dalam meningkatkan prestasi siswa kelas VIII di SMP Negeri 1 Padang Batung untuk dapat membantu dalam menyediakan saranan dan prasaranan untuk mengoptimalkan layanan bimbingan dan konseling.
\end{abstract}

Kata Kunci : Peran guru bimbingan dan konseling, prestasi belajar siswa.

\begin{abstract}
Objects in this study is the role of teachers guidance and counseling to improve student achievement class VIII in SMP Negeri 1 Padang Batung with Subjects of research that is 1 person teachers guidance and counseling in SMP Negeri 1 Padang Batung.Teknik data collection used in this study is interview, observation.

The results of this study show the form of guidance services provided by guidance and counseling teachers to students in improving student achievement class VIII in SMP Negeri 1 Padang Batung Padang Batung Subdistrict Hulu Sungai Selatan Regency by providing guidance services in the classroom and call the students who have learning problems that affect learning achievement counseling and guidance to be given directions, improved and improved in order to become a student who excel in learning achievement.

Based on the results of this study suggested For the school and related agencies on implementing tutoring services in improving the achievement of grade VIII students in SMP Negeri 1 Padang Batung to be able to assist in providing saranan and prasaranan to optimize the guidance and counseling services.
\end{abstract}

Keywords: The role of teacher guidance and counseling, student learning achievement.

Dipublikasikan Oleh:

UPT Publikasi dan Pengelolaan Jurnal

Universitas Islam Kalimantan Muhammad Asyad Al-Banjarmasin 
Dwi Aulia Permatasari, Gusti Irhamni, Didi Susanto Jurnal Mahasiswa BK An-Nur : Berbeda, Bermakna, Mulia

Volume 4 Nomor 1 Tahun 2018

Tersedia Online: https://ojs.uniska-bjm.ac.id/index.php/AN-NUR

ISSN. 2460-9722

\section{PENDAHULUAN}

Pendukung utama tercapainya sasaran pembangunan manusia Indonesia adalah pendidikan yang bermutu. Pendidikan yang bermutu tidak cukup hanya dilakukan melalui transformasi ilmu pengetahuan dan teknologi, tetapi harus didukung oleh peningkatan profesionalisasi dan manajemen tenaga kependidikan serta pengembangan kemampuan peserta didik untuk menolong diri sendiri dan mampu mengambil keputusan demi pencapaian cita-cita.

Pendidikan yang bermutu merupakan pendidikan yang seimbang, mampu menghantarkan peserta didik pada pencapaian standar kemampuan profesional dan akademis, serta mampu membantu perkembangan diri peserta didik yang sehat dan produktif.

Pendidikan nasional berfungsi mengembangkan dan membentuk watak serta peradaban bangsa yang bermartabat dalam rangka mencerdaskan kehidupan bangsa, bertujuan untuk berkembangnya potensi peserta didik agar menjadi manusia yang beriman dan bertakwa kepada Tuhan Yang Maha Esa, berakhlak mulia, sehat, berilmu, cakap, kreatif, mandiri, dan menjadi warga negara yang demokratis serta bertanggung jawab (UUSPN No.20 Th 2003 Bab II Pasal 3)

Pencapaian standar kemampuan profesional/akademis dan tugas-tugas perkembangan peserta didik tersebut memerlukan kerja sama yang baik antara manajemen/supervisi, pengajaran dan bimbingan konseling. Sebab ketiganya merupakan pilar pendidikan yang menjadi pokok dalam pencapaian tujuan pendidikan. Hubungan ketiga pilar pendidikan tersebut diatur dalam pedoman pendidikan di sekolah dan dalam pelaksanaannya diperlukan kerja sama yang baik antara kepala sekolah, guru bidang studi dan guru pembimbing. Guru pembimbing dituntut menguasai kompetensi dasar yang meliputi pemahaman, penghayatan dan keterampilan yang baik dalam melaksanakan kegiatannya dalam bidang bimbingan dan konseling di sekolah.

Suatu sistem layanan bimbingan dan konseling tidak mungkin akan tercipta, terselenggara dan tercapai dengan baik apabila tidak memiliki suatu sistem pengelolaan (manajemen) yang bermutu. Bimbingan dan Konseling adalah pelayanan bantuan untuk peserta didik, baik secara perorangan maupun kelompok, agar mandiri dan berkembang secara optimal, dalam bimbingan pribadi, bimbingan sosial, bimbingan belajar, dan bimbingan karir, melalui berbagai jenis layanan dan kegiatan pendukung, berdasarkan norma-norma yang berlaku (Hariastuti, 2008 : 11).

Manajemen yang bermutu tersebut artinya dilakukan secara jelas, sistematis dan terarah. Untuk itu diperlukan tenaga pendidik, khususnya guru pembimbing yang profesional dalam mengelola sistem layanan bimbingan dan konseling disekolah. Namun, berkaitan dengan pelaksanaan bimbingan dan konseling sampai saat ini pelaksanaan layanan bimbingan konseling di sekolah masih menghadapi berbagai macam persoalan terutama yang bersifat operasional, sehingga sebagian besar masih dirasakan belum menunjukkan hasil yang memuaskan. Keadaan yang demikian berkaitan salah satunya dengan kinerja layanan bimbingan konseling itu sendiri. Berkaitan dengan hal tersebut, guru pembimbing yang ada di lapangan adalah sebagai berikut:

1. Motivasi dan semangat kerja, apatis dan tidak sepenuh hati bekerja

2. Bergaya polsek (polisi sekolah) dan bersikap otoriter.

3. Kurang percaya diri dan merasa minder

4. Emosional, kurang matang dan sabar

5. Kurang terbuka terhadap siswa

6. Kurang tanggap dan kreatif

Sementara itu, dari hasil pengamatan, Senin, 5 Desember 2016, nampak masih ada siswa yang enggan untuk berkonsultasi dengan guru pembimbing seperti siswa mengalami masalah dalam motivasi semangat dalam belajar. Keengganan ini berasal dari perasaan kurang senang siswa terhadap pembimbing, misalnya karena anggapan guru pembimbing yang kurang ramah, cerewet, sehingga guru pembimbing belum mendapatkan apresiasi sewajarnya dari siswa. Sekarang ini banyak sekali para siswa mempersepsikan Guru BK yang negatip mereka bahkan kita pun saat masih ada di bangku sekolah saat mendengar ruang BK pasti yang ada dpikiran kita adalah sebuah hukuman atau mungkin omelan dari Guru BK tersebut. Mungkin ada benarnya juga, kebanyakan siswa yang di panggil langsung oleh guru BK menghadap ruang BK secara 4 mata bisa kemungkinan mereka yang di panggil adalah anak didik yang bermasalah disekolahnya.

Pendapat tersebut mengandung arti bahwa persepsi terhadap guru pembimbing masih keliru. Untuk mengungkap keadaan di balik persoalan yang ada, perlu suatu upaya untuk melihat pokok persoalan yang melatar belakangi keenganan siswa untuk datang kepada guru pembimbing. Upaya tersebut dapat dilakukan melalui sebuah penelitian, dan penelitian tersebut hendaknya menelusuri faktor-faktor yang mempengaruhi guru pembimbing, baik faktor internal maupun faktor eksternal. Faktor eksternal berkaitan dengan hal-hal yang berasal dari luar individu guru pembimbing seperti kurikulum, sarana dan prasarana penunjang, lingkungan kerja guru pembimbing dan sebagainya. Sedangkan faktor internal khususnya menyangkut kemampuan profesional guru pembimbing. Kemampuan profesional guru 
Dwi Aulia Permatasari, Gusti Irhamni, Didi Susanto Jurnal Mahasiswa BK An-Nur : Berbeda, Bermakna, Mulia

Volume 4 Nomor 1 Tahun 2018

Tersedia Online: https://ojs.uniska-bjm.ac.id/index.php/AN-NUR

ISSN. 2460-9722

pembimbing dapat dilihat dari tiga unsur yaitu pengetahuan, keterampilan dan kepribadian yang dimilikinya. Ketiga unsur yang dimiliki oleh guru pembimbing tersebut secara langsung akan mempengaruhi efektivitas layanan bimbingan dan konseling di sekolah.

Karakteristik pribadi guru pembimbing merupakan salah satu unsur penting dalam pelaksanaan layanan bimbingan konseling secara profesional, dan pelaksanaan layanan bimbingan konseling dikatakan berhasil jika dapat memberikan makna bagi para pemakainya, yaitu ditunjukkan dengan adanya kecenderungan atau keinginan para pemakainya untuk memanfaatkan layanan bimbingan konseling secara optimal.

Melalui layanan bimbingan dan konseling peserta didik dibantu mengenal diri dan lingkungannya, serta perencanaan masa depan. Bimbingan diperlukan individu atau sisiwa untuk menciptakan situasi yang dapat menstimulirnya memahami diri dan lingkungan sehingga ia mampu membuat pilihan secara bijak dan tepat di masa mendatang. Dengan demikian, maka bimbingan dan konseling seharusnya diterapkan dan dilaksanakan secara proaktif oleh guru pembimbing atau konselor sesuai kerangka kerja yang telah ditetapkan, dalam hal ini melaksanakan bimbingan pribadi, bimbingan social dan bimbingan belajar. Yang tentu saja sesuai dengan situasi dan kondisi atau keadaan siswa yang membutuhkan hingga tercapainya prestasi belajar peserta didik .

Prestasi belajar adalah suatu kemampuan seorang individu yang nyata yang merupakan hasil interaksi antara berbagai faktor yang mempengaruhi baik dari dalam maupun dari luar individu dalam belajar, kondisi belajar saat ini tidak selamanya sesuai dengan apa yang diharapkan. Banyak siswa yang kemudian tidak dapat mencapai hasil belajar/prestasi belajar yang optimal. Berbagai faktor penyebab pun turut mendukung terjadinya hal tersebut diantaranya jenuh dalam belajar, malas, kurang motivasi, kurang menyenangkan, tidak mengertinya materi yang diajarkan oleh guru. Beberapa diantaranya adalah berkenaan dengan keterampilan-keterampilan belajar yaitu sulit mengingat materi pelajaran, sulit merangkum dari apa yang dibaca, sulit berkonsentrasi, sulit mengembangkan ide dan mencatat dan sebagainya. Sehubungan dengan gambaran peserta didik terhadap pelaksanaan Bimbingan dan konseling yang merupakan salah satu pelayanan pendidikan di sekolah, perubahan paradigm dalam memberikan layanan Bimbingan dan Konseling dari waktu ke waktu menunjukkan bahwa profesi Bimbingan dan Konseling agar bersifat dinamis. Dinamika didalam melaksanakan tugas sebagai guru Bimbingan dan Konseling terjadi karena berbagai faktor, misalnya letak sekolah, ragam masalah, perbedaan individu, dan kesiapan fasilitas sarana prasaran. Oleh karena itu kemampuan mensiasati dan memilih strategi manajemen yang sesuai dengan tuntutan kebutuhan dan perkembangan akan menjadi amunisi yang ampuh untuk mampu menghadapi berbagai dinamika dan perubahan yang dihadapi untuk dimanfaatkan sebagai sarana pengembangan dirinya secara optimal dalam mengejar pretasi belajar.

\section{HASIL DAN PEMBAHASAN}

Layanan bimbingan belajar merupakan upaya untuk membantu siswa dalam mengatasi masalah belajarnya dan untuk bisa belajar dengan lebih efektif. Bentuk layanan bimbingan belajar kelas VIII di SMP Negeri 1 Padang Batung Kecamatan Padang Batung Kabupaten Hulu Sugai Selatan berupa layanan konseling yang dilakukan didalam kelas (classical) ataupun dilakukan diruang bimbingan dan konseling dengan prosedur layanan yang ada dan sesuai dengan kebutuhan peserta didik dengan layanan bimbingan belajar dalam meningkatkan prestasi belajar siswa kelas VIII di SMP Negeri 1 Padang Batung Kecamatan 1 Padang Batung Kabupaten Hulu Sungai Selatan diadakan atau dilakukan setiap ada terjadi kejadian, namun tidak menutup kemungkinan diberikan setiap ada jam kosong atau pun memanggil peserta didik yang memiliki masalah dalam prestasi belajarnya ke ruang bimbingan dan konseling untuk diberikan materi arahan atau nasihat motivasi tentang bagaimana cara belajar yang baik dan benar untuk meningkatkan prestasi belajar setiap individu kelas VIII di SMP Negeri 1 Padang Batung Kecamatan Padang Batung Kabupaten Hulu Sungai Selatan.

Memang tidak semua peserta didik dapat bekerjasama dengan baik, namun efektifitas dari layanan tersebut dirasa sudah cukup. Hal tersebut dapat dilihat dari nilai-nilai peserta didik yang semakin membaik. Peningkatan nila-nilai para peserta didik ini tentu saja menjadi hal yang amat positif mengingat peserta didik yang sudah tingkat VIII dan sebentar lagi akan menghadapi UN. Bagi peserta didik yang masih belum maksimal, akan terus diberikan layanan belajar dengan lebih baik lagi dengan dukungan pihak-pihak terkait.

Hambatan yang di dapat dalam proses pelaksanaan layanan bimbingan belajar di SMP Negeri 1 Padang Batung Kecamatan 1 Padang Batung Kabupaten Hulu Sungai Selatan seperti kurangnya waktu yang tersedia untuk pelaksanaan, tidak ada jam khusus yang disediakan dari pihak sekolah dan hanya mengandalkan jam kosong, kurangnya sarana dan prasarana yang ada disekolah khususnya didalam ruangan bimbingan dan konseling seperti meja yang terlalu besar (meja 
Dwi Aulia Permatasari, Gusti Irhamni, Didi Susanto Jurnal Mahasiswa BK An-Nur : Berbeda, Bermakna, Mulia

Volume 4 Nomor 1 Tahun 2018

Tersedia Online: https://ojs.uniska-bjm.ac.id/index.php/AN-NUR

ISSN. 2460-9722

kerja) serta tidak mempunyai ventilasi udara yang baik seperti kipas angin atau sejenisnya.

Usaha yang dilakukan oleh guru bimbingan dan konseling dalam mengatasi hambatan tersebut yaitu dengan cara berkonsultasi langsung dengan guru mata pelajaran atau dengan kepala sekolah untuk meminta waktu untuk melakukan pelaksanaan layanan bimbingan belajar dan memanfaatkan fasilitas yang ada dalam pelaksanaan layanan bimbingan belajar serta berusaha meminta pengoptimalan saranan dan prasarana demi penujang kelancaran layanan bimbingan belajar yang ada di SMP Negeri 1 Padang Batung Kecamatan Padang Batung Kabupaten Hulu Sungai Selatan.

Dampak layanan bimbingan belajar bagi peserta didik yang serius mengikuti layanan belajar tentu berdampak positif, misalnya saja motivasi peserta didik yang meningkat, sifat dan kebiasaan belajar siswa yang membaik, siswa mulai aktif dalam pembelajaran dan penguasaan materi yang lebih bagus dari sebelumnya.

Wawancara Dengan Peserta Didik Guru bimbingan dan konseling memberikan layanan bimbingan belajar untuk memperbaiki ataupun meningkatkan prestasi belajar peserta didik di kelas VIII dengan memberikan layanan belajar di dalam kelas maupun memanggil peserta didik yang kurang berprestasi untuk meningkatkan prestasinya. Dampak yang sangat dirasakan oleh peserta didik setelah diberikan layanan bimbingan belajar peserta didik menjadi termotivasi untuk dapat membuat prestasi belajar mereka lebih baik lagi. Penyebab terjadinya peserta didik kurang berprestasi dikarenakan peserta didik malas untuk belajar, terlalu banyak menghabiskan waktu untuk hal-hal yang kurang penting, mempunyai kelakuan yang kurang terpuji seperti mengganggu teman dikelas serta mempunyai lingkungan yang negatif. Hal-hal tersebut membuat proses belajar siswa menjadi terganggu dan mengakibatkan prestasi siswa yang semakin turun. Guru bimbingan dan konseling membantu peserta didik dalam mengatasi masalah belajarnya dikarenakan guru bimbingan dan konseling sudah berkewajiban membantu peserta didiknya yang kesulitan dan guru bimbingan dan konseling lah yang dapat optimal membantu peserta didik untuk meningkatkan prestasi belajar peserta didik. Hal ini karena kepekaan seorang guru bimbingan dan konseling dapat dikatakan melebihi guru mata pelajaran lainnya

\section{PENUTUP}

Bentuk layanan bimbingan belajar yang diberikan oleh guru bimbingan dan konseling kepada siswa dalam meningkatkan prestasi belajar siswa kelas VIII di SMP Negeri 1 Padang Batung Kecamatan
Padang Batung Kabupaten Hulu Sungai Selatan dengan cara memberikan layanan bimbingan belajar didalam kelas maupun memanggil siswa yang mempunyai masalah belajar yang mempengaruhi prestasi belajarnya keruang bimbingan dan konseling untuk diberikkan arahan-arahan, diperbaiki dan ditingkatkan agar menjadi siswa yang unggul dalam prestasi belajarnya.

Hambatan yang dihadapi oleh guru bimbingan dan konseling seperti kurangnya waktu pelaksanaan bimbingan belajar karena tidak mempunyai jam khusus, kurangnya sarana dan prasarana khususnya diruangan bimbingan dan konseling seperti ventilasi udara yang tidak memadai ataupun kipas angin yang tidak dimiliki diruang bimbingan dan konseling dan juga meja untuk konselor yang terlalu besar (meja kerja). Faktor-fakor dari siswa seperti malas, kurang mengerti dengan pelajaran, malu bertanya, mengganggu teman sekelas dan tidak bisa membagi waktu belajar dengan baik dan faktor luar diri siswa seperti lingkungan yang negatif ataupun masalah keluarga yang ikut membebani. Dengan layanan bimbingan belajar yang telah dilaksanakan, hambatanhambatan tersebut dirasa sudah cukup teratasi dan prestasi siswa kelas VIII di SMP Negeri 1 Padang Batung Kecamatan Padang Batung Kabupaten Hulu Sungai Selatan yang sebelumnya kurang baik sudah mulai meningka

\section{REFERENSI}

A, Sardiman. 2001. Interaksi dan Motivasi Belajar Mengajar. Jakarta: PT Raja Grafindo Persada.

Hariastuti, dkk, 2008. Dasar-Dasar Bimbingan dan Konseling. Surabaya : Unesa University Press,

Hosnan, M dan Suherman. 2013. Kamus Profesional Guru. Jakarta: Yudistira.

Nana Syaodih Sukmadinata. (2010). Metode Penelitian Pendidikan. Bandung: Remaja Rosdakarya.

Poerwadarminta, W.J.S. 2007. Kamus Umum Bahasa Indonesia Edisi Ketiga. Jakarta: Balai Pustaka.

Prayitno, dkk. (2004). Dasar-dasar Bimbingan dan Konseling. Jakarta: Rineka Cipta 
Dwi Aulia Permatasari, Gusti Irhamni, Didi Susanto Jurnal Mahasiswa BK An-Nur : Berbeda, Bermakna, Mulia

Volume 4 Nomor 1 Tahun 2018

Tersedia Online: https://ojs.uniska-bjm.ac.id/index.php/AN-NUR

ISSN. 2460-9722

Sudjana. 2002. Metoda Statistika. Bandung: Bandung Tarsito.

Sugiyono. 2009. Memahami Penelitian Kualitatif. Bandung : CV. Alfabeta.

Sugiyono. 2013. Metode Penelitian

Pendidikan (Pendekatan

Kuantitatif,Kualitati dan $R \quad \& \quad D$ ). Bandung: Alfabeta.

Suhaji, 2009 Peran Bimbingan Konseling Dalam Meningkatkan Prestasi Belaja Siswa. MTS N Pakem

Sleman Yogyakarta. 09/12/2016

Sukardi, Dewa Ketut. 2008. Bimbingan dan Konseling di Sekolah. Jakarta: Rineka Cipta.

Tu'u, Tulus, 2004, Peran Disipliln pada perilaku dan prestasi Siswa, Jakarta: Gramedia widiasarana.

Undang - undang Sistem Pendidikan Nasional No.20 tahun 2003. Jakarta: Sinar Grafika. 